\title{
Study of vaginal cytology in reproductive age group women attending tertiary care teaching hospital
}

\author{
Singh $\mathbf{N}^{1}$, Purohit $\mathrm{A}^{2}$, Tiwari $\mathrm{V}^{3}$, Shyam $\mathrm{S}^{4}$ \\ ${ }^{1}$ Dr Neelam Singh, Assistant professor, Deparment of obstetrics \& gynaecology, ${ }^{2}$ Dr Ashish Purohit, Assistant professor, \\ Department of medicine. ${ }^{3}$ Dr VarshaTiwari, Assistant professor, Department of Pediatrics, ${ }^{4}$ Dr Saroj Shyam, senior resident, \\ Department of obstetrics\&gynaecology. All are affiliated with LN medical college, Bhopal (MP) India.
}

Address for correspondence: Dr Varsha Tiwari, Email: dr.varshatiwari021@ gmail.com

\begin{abstract}
Introduction: Lesions of the cervix are the commonest causes of chronic ill health in gynecological practices. The cervix is a specially modified part of uterus with a histological and physiological entity of its own. It probably constitutes the most neglected and damaged part of female body. The accurate study of these vaginal and cervical lesions are needed because of chronic disability of the patient in the form of low backache, vaginal discharge, primary or secondary sterility and later predisposition to malignancy. Material and Methods: A total of 200 smears were studied from 200 women of reproductive age group attending gynecological outpatient department and antenatal clinic of Tertiary care teaching hospital of central India who complained of symptoms like backache, discharge, and irregular vaginal bleeding. A detailed clinical and vaginal examination was done in every case and smears were collected for exfoliative cytology. Analysis of results was done by Odds ratio and multivariate logistic regression. Results: 200 clinically diagnosed cases of benign lesions of cervix were taken up for detailed clinical and cytological study. Erosion was the commonest among all benign lesions, which was 58.5\%. Next common lesion was chronic cervicitis (20\%) \&chronic cervicitis with erosion (9\%) on cytological examination. Conclusions: Nonmalignant cervical lesions are extremely common. Cervical erosion and non- specific cervicitis are most frequently encountered. These are frequent cause of morbidity in women of reproductive age group, which if neglected progresses to malignancy with significant morbidity and mortality. Close follow up and histiologic examinations are necessary to avoid unnecessary spread of neoplastic disease and untimely death of patients. Awareness about diseases in women of reproductive age group and diagnostic utility of papanicolau smear test is also a must.
\end{abstract}

Keywords: Cervical, Cytology, Papanicolau Smear.

\section{Introduction}

Cervical cancer is important public health problem among adult women in many developing countries and is second most common cancer in female worldwide[1,2]. The National Cancer Registry programme in India has reported that cancer of the cervix is the most important cancer in women in India, over past two decades and that the estimated number of new cancers during 2007 in India was $90,708[3]$.

Cervical cytology became the standard screening test for cervical cancer and premalignant cervical lesions with the introduction of the Papanicolaou (Pap) smear in 1941[4].one out of every five women in the world is suffering from this disease is belong to India [5].More than three forth of these patients are diagnosed at advanced stages leading to poor aspects of long term survival and cure[6].

Manuscript received: $13^{\text {th }}$ Mar 2015

Reviewed: $22^{\text {th }}$ Mar 2015

Author Corrected: $16^{\text {th }}$ Apr 2015

Accepted for Publication: $2^{\text {nd }}$ May 2015

International Journal of Medical Research and Review
In India, despite the public health importance that cervical cancer merits, there are only sporadic efforts in hospitals and research settings for early detection and prevention. Regular population-based screening using Pap smear cytology is the internationally accepted screening method for cervical cancer. The health infrastructure and organizational aspects for such a screening program, based purely on the Pap smear are not available in India at present due to lack of trained personnel and laboratory facilities. The United States Preventive Services Task Force (USPSTF) has recommended regular screening of women to decrease load of cancer cervix morbidity [7].

Vaginal smear examination is not recommended as a means of final and ultimate diagnosis but it may be used as a preliminary sorting out procedure and screening test, andas a matter of fact should always be confirmed by tissue biopsy.

In this study it is proposed to diagnose the cases clinically and to study the cytological pattern in vaginal smears.

Available online at: www.ijmrr.in 414 | P a g e 


\section{Material and Method}

It was basically an observational study of available pap smears received in the cytopathology lab from women attending the gynecological out-patient department at the Sultania Zanana hospital which is a tertiary care teaching hospital in central India.

The smears were of patients attending Gynecological outpatient department and in whom Pap smear was advised by the treating gynecologist for clinical indications.The patients were instructed by the gynecologists prior to the procedure, for example avoid coitus, use of local douching and antiseptics before the cytological examination. After per speculum examination of the patient, the longer projection of Ayer's spatula was inserted in cervix near squamo-columnar junction and

\section{Research Article}

rotated through $360^{\circ}$. The material obtained was quickly smeared on glass slide and put in the fixative jar containing 95\% ethyl alcohol. The pap staining was done by trained cytotechnologists followed by light microscopy and slide interpretation by cytopathologists, according to new Bethesda system, 2001.

The inclusion criteria of the study population consisted of women of 16 - 50years who complained of symptoms like backache, discharge, and irregular vaginal bleeding and the patients who complained of no symptoms and the cervical lesion was found on routine examination.

The exclusion criteria were women within 6 weeks following delivery or abortion, women with already detected cancer cervix revealed from history or records, and women refusing consent.

\section{Results}

In the present series of work, a total of 200 smears were studied from 200 women attending gynecologicaloutpatient department and antenatal clinic of SultaniaZanana Hospital. Out of these 200 women, 50 women were pregnant at the time of examination 13 women of 150 women of primary sterility. 200 clinically diagnosed cases of benign lesions of the cervix were taken up for detailed clinical and cytological examination.

Table No 1: Shows different type of lesions seen in these cases

\begin{tabular}{|l|l|l|}
\hline Lesions & No. of cases & Percentage \\
\hline Erosion & 117 & 58.5 \\
\hline Chronic cervicitis & 40 & 20 \\
\hline Chronic cervicitis with Erosion & 18 & 9 \\
\hline Endocervicitis & 14 & 7 \\
\hline Cervical polyp & 4 & 2 \\
\hline Carcinoma cervix & 1.0 & 0.5 \\
\hline Metaplasia & 6 & 3 \\
\hline
\end{tabular}

The above table shows that the erosion is the commonest among all the benign lesions, which is $58.5 \%$. Next common lesion is chronic cervicitis $19 \% .6$ out of seven cases of suspicious cervix showed metaplasia on cytological examination.

Table No 2: Presenting symptoms of cases

\begin{tabular}{|l|l|l|l|}
\hline S. No & Symptoms & No.of cases & Percentage \\
\hline 1. & Leucorrhoea & 119 & 59.5 \\
\hline 2. & Abdominal pain & 42 & 21 \\
\hline 3. & Backache & 56 & 28 \\
\hline 4. & Dysuria & 22 & 11 \\
\hline 5. & Pruritus & 24 & 12 \\
\hline 6. & Post coital bleeding & 3 & 1.5 \\
\hline 7. & Dysmenorrhea & 10 & 5 \\
\hline 8. & Menorrhagia \&metrorhagia & 39 & 19.5 \\
\hline 9. & Primary \& secondary sterility & 22 & 11.0 \\
\hline 10 & Secondary Amenorrhea & 2 & 1 \\
\hline 11 & Miscellaneous & 19 & 9.5 \\
\hline
\end{tabular}


It is clear from above table no. 2 that leucorrhea, backache, abdominal pain and menstrual disturbance were the commonest complains in most of these patients.

Incidence of various lesions of the cervix was studied in relation to age, parity, and socioeconomic factors.

Table No 3: Incidence of cervical erosion according to various age groups

\begin{tabular}{|l|l|l|l|l|}
\hline $\begin{array}{l}\text { Age group } \\
\text { in years }\end{array}$ & $\begin{array}{l}\text { Non pregnant } \\
\text { cases 150 }\end{array}$ & Percentage & $\begin{array}{l}\text { Pregnant cases } \\
\mathbf{5 0}\end{array}$ & Percentage \\
\hline $20-25$ & 21 & 14 & 14 & 28 \\
\hline $26-30$ & 32 & 21.4 & 16 & 32 \\
\hline $31-35$ & 16 & 10.6 & 3 & 6 \\
\hline $36-40$ & 6 & 4 & 9 & 18 \\
\hline
\end{tabular}

The above table shows that incidence of cervical erosion is highest between 26 to 30 .

Table No 4: Incidence of cervical erosion in relation to parity

\begin{tabular}{|l|l|l|l|l|}
\hline Parity & $\begin{array}{l}\text { Non pregnant } \\
\text { Cases 150 }\end{array}$ & Percentage & $\begin{array}{l}\text { Pregnant Cases } \\
\text { 50 }\end{array}$ & Percentage \\
\hline Nulliparous & 4 & 2.6 & -- & -- \\
\hline Primiparous & 18 & 12.0 & 13 & 26 \\
\hline Multiparous & 53 & 34.6 & 29 & 58 \\
\hline
\end{tabular}

Incidence of cervical erosion found to be greater in multi para as compared to primipara and it was least in patients who have never conceived.

\section{Discussion}

The incidence of benign lesions of the cervix though, it varies from clinic to clinic, still remain fairly high. The incidence in present series has been found to be $15 \%$ among antenatal and gynecological patients. The cervix is specially modified part of uterus with histological and physiological entity of its own. It probably constitutes most neglected part of the female body. No other portions of body undergoes such profound changesand is predisposed to traumas. As the cervix is hidden and the women do not feel much pain or inconvenience, it is most neglected.It affects preferentially the squamocolumnar junction and the endocervix and is often accompanied by metaplastic changes in the epithelium. On the other hand, cancer of the cervix is recognized as the leading cause of cancer in women in India[8]. Medical literature is replete with the studies in which cytology screening has resulted in reduction of cervical cancer burden women cancer cervix is consider to be a ideal malignancy for screening, aimed at detecting premalignant conditions before they progress to invasive cancer $[9,10]$.

The incidence in the present series has been found to be $15 \%$ among antenatal and gynecological patients. Rana, et alobserved $6.8 \%$ epithelial abnormality on pap smear cytology in Delhi [11]. In contrast, a Turkish primary health centre based study showed atypical epithelial cells in only $0.8 \%$ of the cases.[12]. Cervical cancer is relatively less prevalent in Turkey and is the eighth most common cancer type, in terms of both incidence and cause of death in Turkey which was reflected in a study[12].

A Dutch study conducted by Roeterset al. which over 1 million cervical smears were analyzed, concluded that cervical smear examination is a valuable tool in the diagnosis of cervical infections [13].

Trichomonasvaginalis was seen in $5.5 \%$ women in our study. Rana et al found $2.5 \%$ Previous studies have reported the association of ASCUS (Atypical Squamous Cells of Undetermined Significance) in a significant proportion of women with Trichomonasvaginalisinfection[14,15]. In our study, out of the 12 cases of ASCUS, an inflammatory etiology was favored in 7 cases, though no causative agent was identified in any of them. We found $9 \%$ cases of Candidial infection seen along with a dense neutrophilic infiltrate and a necrotic background. No other fungal infections were detected in this study. Four cases were suggestive of HSV and a similar incidence was noted in the Pakistan based study of Bukhariet al.[14] However a much higher incidence of HSV was observed in a study of cervical cytology of women in their third trimester of pregnancy. [16] Ten cases showed koilocytosis without 
atypia, features suggestive of HPV infection. In an attempt to improve the sensitivity of cytologic diagnosis of HPV infections.Schneider et al.[17] described five important criteria i.e. mild koilocytosis, mild dyskeratocytosis, hyperchromatic nuclei, bi and multinucleation and cleared cytoplasm. These criteria were used in combination which identified majority of HPV infected cases [17]. In this cervical cytology screening study of 200 cases we found the mean age of patients with ASCUS to be 26-30 years, which correlated with similar findings in other studies[1,2,3,17,18,19]. The latest recommendations by the U.S. Preventive Services Task Force (USPTF) issued in June 2012 advise screening for cervical cancer in women aged 21 to 65 years with cytology(Papanicolaou smear) every 3 years or, for women aged 30 to 65 years who want to lengthen the screening interval, screening with a combination of cytology and HPV testing every 5 years[21]. The incidence of abnormal epithelial cell lesion in the present study was $15 \%$. The prevalence rates published in previous studies ranged from 1.66-7.9\% [22-24]. Studies done on the prevalence of epithelial cell abnormality have shown $4.3 \%$ in Kuwait [25] $7.9 \%$ in South west Saudi Arabia [19] and 4.95\% in Eastern Saudi Arabia[26]. These studies showed an overall prevalence of the epithelial abnormalities similar to the current study.

\section{Conclusion}

Prevention plays an equally important role in gynaecological conditions. With a better care of antenatal and postnatal cases, control of infections with antibiotic, better method of labour conduction and immediate repair of cervical tear during the deliveries, incidence of these cervical lesions have been reduced to a considerable extent.ThePapanicolaou (Pap) test is widely regarded as a cost effective cancer screening test and as a simple method to detect cervical lesions at an early stage.

Funding: Nil, Conflict of interest: None initiated. Permission from IRB: Yes

\section{Bibliography}

1. Adhikary AK, Banik U, Numaga J, Suzuki E, Inada T,Okabe N. Heterogeneity of the fibre sequence in subgenusC adenovirus.JClinPathol. 2004 Jun;57(6):612-7.

2. Toews HA. The abnormal PAP smear: A rationale for follow up. Can Fam Physician. 1983 Apr;29:759-62.

3. National Cancer Registry Programme (NCRP, ICMR). Time trends in cancer incidence rates: 1982-2005. Bangalore:NCRP; 2009.
4. Papanicolaou GN, Traut HF. The diagnostic value of vaginalsmears in carcinoma of the uterus 1941. Arch Pathol Lab Med. 1997 Mar;121(3):211-24.

5.World health organization.cervical cancer screening programme managerial guidelines.Geneva :WHO;2006Annals of Oncology 17 (Supplement 8): viii9-viii14, 2006 symposium article doi:10.1093/annonc/md1982.Available

fromnonc.oxfordjournals.org cited on feb 2015.

6.Guidelines for cervical cancer screening program Recommendations of expert group meeting. Government of india - world health organization collaborative programme (2004-2005), Department of Cytology \& Gynaecological Pathology Postgraduate institute of medical education and Reasearch, Chandigarh India, November 2006.Available from http://screening.iarc.fr/doc/WHO_India_CCSP_guidelines _2005.pdf cited on feb 2015.

7. Screening for Cervical Cancer Recommendations and Rationale; US Preventive Services Task Force Recommendations, 2003. Available from http://www.ahrq.gov/clinic/3rduspstf/cervcan/cervcanrr.p df. Cited on 12th Feb 2015

8. Nandkumar A, Ramnath T, Chaturvedi M. The magnitude of cancer cervix in India Indian $\mathrm{J}$ Med Res. 2009 Sep;130(3):219-21.

9. Rader $\mathrm{AE}^{1}$, Rose $\mathrm{PG}$, Rodriguez M, Mansbacher S, Pitlik D, Abdul-Karim FW. Atypical Squamous cells of undetermined significance in women over 55.Comparison with the general population and implications for management. Acta Cytol. 1999 May-Jun;43(3):357-62.

10. Burja IT, Thompson SK. Atypical glandular cells of undetermined significance in women over age 55. Acta Cytol1 999;43:356-7.Available from www.amhsjournal.org/article.Cited on feb2015 .

11. Rana S, Jairajpuri ZS, Jetley S. Cervical smear cytology on routine screening in a semi urban population in New Delhi: A review of 610 cases. Arch Med Health Sci 2013;1:131-5 Available from: http://www.amhsjournal.org/text.asp?2013/1/2/131/12302 5Cited on feb 2015 .

12. Demirhindi H, Nazhcan E, Akbaba M. Cervical cancerscreening in Turkey: A community based experience after 60 years of Pap Smear usage. Asian Pac J Cancer Prev2012;13:6497-500. Available from www.amhsjournal.org/articleCited on feb2015 .

Available online at: www.ijmrr.in 417 | P a g e 
13. Roeters AM, Boon ME, van Haaften M, Vernooij F, BontekoeTR, Heintz AP. Inflammatory events as detected in cervical smears and squamous intraepithelial lesions. Diagn Cytopathol 2010;38:85-93.

14. Bukhari MH, Majid M, Qamar S, Niazi S, Syed SZ, Yusuf AW,et al. Clinicopathological study of Papanicolaou (Pap) smearsfor diagnosing of cervical infections. Diagn Cytopathol 2010;40:35-41. Available from www.amhsjournal.org Cited on12th Feb2015.

15. Tirone NR, Souza CE, Michelin MA, Murta EF. Frequency of infectious agents for vaginitis in patients with a cytological diagnosis of atypical squamous cells of undetermined significance. Eur J GynaecolOncol2008;29(2):144-7.

16. Rimdusit P, Yoosook C, Srivanboon S, Sirimong kolkasem R, Pumeechockchai W. Prevalence of genital herpes simplex infection and abnormal vaginal cytology in late pregnancy in asymptomatic patients. Int $\mathbf{J}$ Gynaecol Obstet 1989;30:231-6. Available from www.amhsjournal.orgCited on feb2015 .

17. Wihite LN. An overview of screening and early detection ofgynaecologicmalignancies.Cancer. 1993 Feb 15;71(4 Suppl):1400-5.

18. Martin-Hirsch P, Lilford R, Jarvis G, Kitchener HC. Efficacyof cervical-smear collection devices: A systematic reviewand meta-analysis.Lancet. 1999 Nov 20;354(9192):1763-70.

19. Solomon D, Davey D, Kurman R, Moriarty A, O'Connor D,Prey M, et al. The 2001 Bethesda System: Terminology forreporting results of cervical cytology. JAMA 2002;287:2114-9.
20. Rader AE, Rose PG, Rodriguez M, Mansbacher S, PitlikD,Abdul-Karim FW. Atypical Squamous cells of undeterminedsignificance in women over 55.Comparison with the generalpopulation and implications for management.ActaCytol1999;43:357-62.

21. Moyer VA. U.S. Preventive Services Task Force.Screeningfor cervical cancer: U.S. Preventive Services Task Forcerecommendationstatement..Ann Intern Med. 2012 Jun 19;156(12):880-91, W312. doi: 10.7326/0003-4819-156-12-201206190-00424.

22. Afrakhteh M, Khodakarami N, Moradi A, Alavi E, Shirazi FH.A study of 13315 Papanicolaou smear diagnoses in Sohada hospital. J FamReprod Health 2007; 1:75-9.

23. Jamal A, Al Maghrabi JA. Profile of PAP smear cytology in thewestern region of Saudi Arabia. Saudi Med J 2003;24:1225-9.

24. Altaf FJ. Cervical cancer screening with pattern of papsmear. Review of multicenter studies. Saudi Med J 2006;27:1498-502.

25. Kapila K, George SS, Al-Shaheen A, Al Ottibi MS, PathanSK, Sheikh ZA, et al. Changing spectrum of squamous cellabnormalities observed on papanicolaou smears in MubarakAlKabeer Hospital, Kuwait, over a 13 year period. Med PrincPract 2006;15:253-9.

26. Balaha MH, Al Moghannum MS, Al Ghowinem N, Al OmranS. Cytological pattern and cervical Papanicolaou smear ineastern region of Saudi Arabia. J Cytol 2011;28:173-7.Available from www.jcytol.org/article.Cited on 13th Feb

\section{How to cite this article?}

Singh N, Purohit A, Tiwari V, Shyam S. Study of vaginal cytology in reproductive age group women attending tertiary care teaching hospital. Int J Med Res Rev 2015;3(4):414-418. doi: 10.17511/ijmrr.2015.i4.081. 